\title{
LETTER TO EDITOR
}

(JANUARY 2, 2014)

\section{DOES THE RINGTONE OR RADIOFREQUENCY RADIATION OF A MOBILE PHONE AFFECT REACTION TIME OF ITS OWNER?}

\section{Dear Editor,}

I have read with a great interest the article by Zajdel et al. entitled "Cell phone ringtone, but not landline phone ringtone, affects complex reaction time" that was published in the March 2013 issue of the "International Journal of Occupational Medicine and Environmental Health" [1]. The authors have also published another paper entitled "The sound of a mobile phone ringing affects complex reaction time of its owner" [2].

In these reports, the authors have concluded that ringing of a mobile phone, but not of a landline phone, significantly alters human reaction time. Over the past years, our laboratory has focused on studying health effects of exposure of laboratory animals and humans to some common and/or occupational sources of electromagnetic fields such as mobile phones [3-10] and their base stations [11], mobile phone jammers [12], laptop computers [13], radars [4], dentistry cavitrons [14] and MRI [9].

Zajdel et al. have not paid attention to the facts that: firstly, mobile phones emit electromagnetic radiation in the microwave region and secondly, microwave radiation can alter the reaction time in humans [4,5]. Mortazavi et al. have previously shown that the visual reaction time of university students was significantly affected by a short term exposure (10 $\mathrm{min})$ to electromagnetic fields (EMF) emitted by a common mobile phone [4]. This experiment revealed that such a short term exposure can decrease reaction time. Mortazavi et al. have also shown that microwave radar radiations can decrease the reaction time in radar workers [4]. Alterations in the speed of information processing and the increased consumption of glucose in the brain following exposure to radiofrequency radiation, which is confirmed by PET studies, are believed to be potential mechanisms in this phenomenon. I hope that these comments will be useful in obtaining more reliable results in the future.

\section{Key words:}

Mobile phone, Electromagnetic fields,

Microwave, Reaction time

\section{REFERENCES}

1. Zajdel R, Zajdel J, Śmigielski J, Nowak D. Cell phone ringtone, but not landline phone ringtone, affects complex reaction time. Int J Occup Med Environ Health. 2013;26(1): $102-12$.

2. Zajdel R, Zajdel J, Zwolinska A, Smigielski J, Beling P, Ceglinski $\mathrm{T}$, et al. The sound of a mobile phone ringing affects the complex reaction time of its owner. Archiv Med Sci AMS. 2012;8(5):892-8.

3. Mortazavi SMJ, Motamedifar M, Namdari G, Taheri M, Mortazavi AR, Shokrpour N. Non-linear adaptive phenomena which decrease the risk of infection after pre-exposure to radiofrequency radiation. Dose Response. Forthcoming 2014.

4. Mortazavi SMJ, Taeb S, Dehghan N. Alterations of visual reaction time and short term memory in military radar personnel. Iranian J Publ Health. 2013;42(4):428-35.

5. Mortazavi SMJ, Rouintan MS, Taeb S, Dehghan N, Ghaffarpanah AA, Sadeghi Z, et al. Human short-term exposure 
to electromagnetic fields emitted by mobile phones decreases computer-assisted visual reaction time. Acta Neurologica Belgica. 2012;112(2):171-5.

6. Mortazavi SMJ, Mosleh-Shirazi MA, Tavassoli AR, Taheri M, Mehdizadeh AR, Namazi SAS, et al. Increased radioresistance to lethal doses of gamma rays in mice and rats after exposure to microwave radiation emitted by a GSM mobile phone simulator. Dose Resp. 2013;11(2):281-92.

7. Mortazavi S, Mosleh-Shirazi M, Tavassoli A, Taheri M, Bagheri Z, Ghalandari R, et al. A comparative study on the increased radioresistance to lethal doses of gamma rays after exposure to microwave radiation and oral intake of flaxseed oil. Iran J Radiation Res. 2011;9(1):9-14.

8. Mortazavi SMJ, Habib A, Ganj-Karimi AH, Samimi-Doost R, Pour-Abedi A, Babaie A. Alterations in TSH and thyroid hormones following mobile phone use. OMJ. 2009;24:274-8.

9. Mortazavi SMJ, Daiee E, Yazdi A, Khiabani K, Kavousi A, Vazirinejad R, et al. Mercury release from dental amalgam restorations after magnetic resonance imaging and following mobile phone use. Pak J Biol Sci. 2008;11(8):1142-6.

10. Mortazavi SMJ, Ahmadi J, Shariati M. Prevalence of subjective poor health symptoms associated with exposure to electromagnetic fields among University students. Bioelectromagnetics. 2007;28(4):326-30.
11. Mortazavi SMJ. Safety issue of mobile phone base stations. J Biomed Phys Eng. 2013;3(1):1-2.

12. Mortazavi SMJ, Parsanezhad ME, Kazempour M, Ghahramani P, Mortazavi SAR, Davari M. Male reproductive health under threat: short term exposure to radiofrequency radiations emitted by common mobile jammers. J Human Reprod Sci. 2013;6(2):124-8.

13. Mortazavi SMJ, Tavasoli AR, Ranjbari F, Moamaei P. Effects of laptop computers' electromagnetic field on sperm quality. J Reprod Infertil. 2011;11(4):251-8.

14. Mortazavi SM, Vazife-Doost S, Yaghooti M, Mehdizadeh S, Rajaie-Far A. Occupational exposure of dentists to electromagnetic fields produced by magnetostrictive cavitrons alters the serum cortisol level. J Nat Sci Biol Med. 2012;3(1):60-4.

Seyed Mohammad Javad Mortazavi (PhD, Professor of Medical Physics) Medical Physics \& Medical Engineering Department School of Medicine, Zand Street, Post Code No. 7134845794

Setad Square, Shiraz, Iran (e-mail: mmortazavi@sums.ac.ir)

This work is available in Open Access model and licensed under a Creative Commons Attribution-NonCommercial 3.0 Poland License - http://creativecommons.org/ licenses/by-nc/3.0/pl/deed.en. 